\title{
Visceral leishmaniasis in Brazil: trends and challenges
}

\author{
Leishmaniose visceral no Brasil: \\ evolução e desafios
}

\author{
1 Secretaria de Vigilância em \\ Saúde, Ministério da Saúde, \\ Brasília, Brasil. \\ 2 Instituto de Medicina \\ Tropical, Universidade de São \\ Paulo, São Paulo, Brasil. \\ Correspondence \\ A. N. S. Maia-Elkhoury \\ Departamento de Vigilância \\ Epidemiológica, Secretaria \\ de Vigilância em Saúde, \\ Ministério da Saúde. \\ Rua 8 Sul, Lotes 10/12, \\ Bloco C, apto. 702, Brasília, \\ DF 71938-180, Brasil. \\ ana.elkhoury@saude.gov.br
}

\section{Abstract}

The urbanization of visceral leishmaniasis in Brazil has been related to environmental changes, migration, interaction and spread of sylvatic reservoirs and infected dogs to areas with no transmission, and adaptation of the vector Lutzomyia longipalpis to the peridomiciliary environment. From 1980 to 2005, Brazil recorded 59,129 cases of visceral leishmaniasis, $82.5 \%$ of which in the Northeast region. Visceral leishmaniasis gradually spread to other regions of the country: in 1998 these other regions reported 15\% of all cases, but by 2005 this proportion had increased to 44\%. From 1998 to 2005, indigenous cases were reported in 1,904 different municipalities of the country (34.2\%). Reservoir and vector control pose major challenges for disease control, since there is a need for better knowledge of vector behavior in urban areas, and control activities involve high operational costs. In recent years the Brazilian Ministry of Health has supported research on the laboratory diagnosis of infection and disease in humans and dogs, treatment of patients, evaluation of the effectiveness of control strategies, and development of new technologies that could contribute to the surveillance and control of visceral leishmaniasis in the country.

Disease Reservoirs; Vector Control; Visceral Leishmaniasis; Urbanization; Epidemiological Surveillance

\author{
Ana Nilce Silveira Maia-Elkhoury ${ }^{1}$ \\ Waneska A. Alves 1 \\ Márcia Leite de Sousa-Gomes 1 \\ Joana Martins de Sena 1 \\ Expedito A. Luna 2
}

Visceral leishmaniasis is a zoonosis characterized by chronic evolution and systemic involvement, which if untreated results in death in $90 \%$ of cases. It is caused by different species of genus Leishmania, and in the Americas L. (L.) chagasi is the etiological agent of the disease. Visceral leishmaniasis is transmitted by a vector belonging to the family Psychodidae and genus Lutzomyia, and in Brazil the principal vector is Lu. longipalpis. In 1998, $\mathrm{Lu}$. cruzi was identified as the vector in Corumbá, Mato Grosso do Sul, and evidence of transmission of visceral leishmaniasis by this species was recently described in the municipality (county) of Jaciara, Mato Grosso 1,2,3,4,5,6.

The potential sylvatic reservoirs are fox ( $\mathrm{Lyca}$ lopex vetulus and Cerdocyon thous) and opossum (Didelphis albiventris). Dogs (Canis familiaris) are domestic reservoirs of $L$. (L.) chagasi and are identified as the vector's principal source of infection 7,8,9,10,11,12.

Visceral leishmaniasis is endemic in 65 countries, with 500 thousand new cases reported annually, $90 \%$ of which are concentrated in India, Nepal, Sudan, Bangladesh, and Brazil 5 (with the latter accounting for approximately $90 \%$ of cases in the Americas).

The first report of a case of visceral leishmaniasis in Brazil was in 1913, in a patient from Boa Esperança, Mato Grosso ${ }^{13}$. Afterwards, it was not until 1934 that more cases of the disease were reported, based on post-mortem viscerotomy in 41 patients from the Northeast who had been 
suspected of yellow fever ${ }^{14}$. Until the early 1950s, only 379 cases of visceral leishmaniasis had been reported, distributed in 13 States, and it was believed that visceral leishmaniasis transmission was exclusively rural or sylvatic $15,16,17$.

However, in the 1950s, a study in Sobral, Ceará State, showed that of the 177 patients that were examined, $96 \%$ had been infected in rural areas such as foothills, hollows, and grottos. Meanwhile $4 \%$ (7) of the patients had been infected in the urban area of Sobral, as confirmed by cases of canine infection in a survey 18 . Since the 1970s, urbanization of the disease has intensified, especially on the urban peripheries and in the so-called transition zones of medium and large cities 15 .

It is believed that urbanization of visceral leishmaniasis results from anthropogenic environmental alterations and the rapid and intense migration of rural populations to urban peripheries that lack adequate housing and sanitation infrastructure, with the concurrent interaction and mobilization of sylvatic reservoirs and dogs infected with $L$. (L.) chagasi to areas without visceral leishmaniasis transmission 19,20. Furthermore, it has been observed that Lu. longipalpis, responsible for transmission of the disease, has adapted easily to the peridomicile, facilitated by factors still not completely understood, but possibly related to those mentioned above, along with the maintenance of conditions favoring the vector's breeding in this setting and the species' development of capacity to cohabit anthropic environments 21,22 .

Over the last 30 years, transmission of visceral leishmaniasis has been described in medium and large cities in various Brazilian municipalities, and in particular since the 1980s, cases and outbreaks of human visceral leishmaniasis have been reported, with indigenous transmission within city limits in São Luís (Maranhão), Teresina (Piauí), Natal (Rio Grande do Norte), Aracajú (Sergipe), Fortaleza (Ceará), Rio de Janeiro, Corumbá (Mato Grosso do Sul), and Montes Claros and Sabará (Minas Gerais). In the early 1990s, more municipalities reported outbreaks of visceral leishmaniasis in urban areas, as in Belo Horizonte (Minas Gerais), Feira de Santana (Bahia), Várzea Grande (Mato Grosso), Araçatuba (São Paulo), Aquidauana (Mato Grosso do Sul), and others, and since 2000 new urban epidemics have been reported in the municipalities of Palmas (Tocantins), Três Lagoas and Campo Grande (Mato Grosso do Sul), Caxias, Timon, Codó, and Imperatriz (Maranhão), Bauru (São Paulo), Paracatu (Minas Gerais), Cametá (Paraná), and others 12,19,23,24.

With the urbanization of visceral leishmaniasis, from 1980 to 2005 Brazil recorded 59,129 new cases of the disease, with an annual mean of 2,274 new cases. Of all the cases, $82.5 \%(48,783)$ occurred in the Northeast region. Visceral leishmaniasis gradually spread to the Central-West, North, and Southeast, increasing from $15 \%$ of the cases in 1998 to $44 \%$ in 2005. Currently, 20 (74\%) of the States of Brazil are recording indigenous cases.

From 1998 to 2005, indigenous cases of the disease were recorded in 1,904 (34.2\%) different Brazilian municipalities (counties). Table 1 shows that the number of municipalities with cases of visceral leishmaniasis varies from year to year, as do the means and ranges of cases, suggesting intensification of the disease in some municipalities, as well as the transmission of human visceral leishmaniasis in new municipalities.

Table 2 shows a decrease in the number of municipalities without transmission of visceral leishmaniasis and an increase in new areas with transmission of the disease in the country, but approximately $82 \%$ of the municipalities with reported cases are classified as having sporadic transmission (mean of fewer than 2.4 cases in the last 5 years). During the periods analyzed, there was a mean/period of 150 municipalities with intense transmission of visceral leishmaniasis (mean of $\geq 4.4$ cases in the last 5 years) and 141 with moderate transmission (mean cases in the last 5 years: $\geq 2.4$ and $<4.4$ ), indicating that the cases of visceral leishmaniasis are concentrated in some $5 \%$ of Brazilian municipalities (Figure 1).

Despite the increase in cases recorded in the last 12 years, a recent study linking different data sources in the Unified National Health System (SUS) and using the capture-recapture method allowed estimating the cases and underreporting of visceral leishmaniasis in Brazil as a whole and in some specific municipalities. The National Database on Reportable Diseases (SINAN) show $42 \%$ underreporting of cases when compared to the visceral leishmaniasis records in the Hospital Information System (SIH) and 45.5\% when compared to the Mortality Information System (SIM). Furthermore, this underreporting varied between municipalities, given the different organizational formats in the municipal and hospital surveillance systems 25 .

The mean incidence of visceral leishmaniasis in the last 12 years was 2 cases/100,000 inhabitants and the case-fatality rate was $5.5 \%$, emphasizing an increase of $117 \%$ in 2005 (6.9\%) when compared to the case-fatality rate in 1994 (3.2\%). The distribution of visceral leishmaniasis in Brazil is cyclical, with an increase in cases at average intervals of some five years, but this trend varies between the different municipalities and States. 
Distribution of municipalities (counties) by occurrence of visceral leishmaniasis cases and year of reporting. Brazil, 1998-2005.

\begin{tabular}{|c|c|c|c|c|c|c|}
\hline Year * & $\begin{array}{c}\text { Municipalities } \\
\text { with cases } \\
(\mathrm{N}=5,561)\end{array}$ & Mean \pm SD ** & 2nd quartile & Median *** & 3rd quartile & Range \\
\hline 1998 & 521 & $3.8 \pm 9.3$ & 1 & 2 & 3 & $1-113$ \\
\hline 1999 & 688 & $5.3 \pm 13.5$ & 1 & 2 & 4 & $1-186$ \\
\hline 2000 & 867 & $5.5 \pm 13.3$ & 1 & 2 & 5 & $1-203$ \\
\hline 2001 & 839 & $4.3 \pm 9.5$ & 1 & 2 & 4 & $1-121$ \\
\hline 2002 & 690 & $4.5 \pm 13.3$ & 1 & 2 & 3 & $1-192$ \\
\hline 2003 & 572 & $5.4 \pm 17.9$ & 1 & 2 & 3 & $1-291$ \\
\hline 2004 & 728 & $4.6 \pm 12.6$ & 1 & 2 & 3 & $1-177$ \\
\hline 2005 & 747 & $5.0 \pm 12.6$ & 1 & 2 & 3 & $1-154$ \\
\hline
\end{tabular}

Source: Health Surveillance Secretariat, Ministry of Health.

* Year of occurrence of cases of visceral leishmaniasis;

** Mean number of cases by year and municipality;

*** Median number of cases by year and municipality.

Table 2

Distribution of municipalities with and without reported cases of visceral leishmaniasis, by year of occurrence and stratification of transmission areas. Brazil, 1998-2005.

\begin{tabular}{|c|c|c|c|c|c|c|c|c|c|c|}
\hline \multirow[t]{3}{*}{ Period * } & \multicolumn{4}{|c|}{ Municipalities ( $N=5,561$ ) } & \multicolumn{6}{|c|}{ Transmission } \\
\hline & \multicolumn{2}{|c|}{ With cases } & \multicolumn{2}{|c|}{ Without cases } & \multicolumn{2}{|c|}{ Sporadic ** } & \multicolumn{2}{|c|}{ Moderate $* \star \star$} & \multicolumn{2}{|c|}{ Intense \# } \\
\hline & $\mathrm{n}$ & $\%$ & $\mathrm{n}$ & $\%$ & $\mathrm{n}$ & $\%$ & $\mathrm{n}$ & $\%$ & $\mathrm{n}$ & $\%$ \\
\hline 1998-2002 & 1,595 & 28.7 & 3,966 & 71.3 & 1,281 & 23.0 & 152 & 2.7 & 162 & 2.9 \\
\hline 1999-2003 & 1,653 & 29.7 & 3,908 & 70.3 & 1,356 & 24.4 & 144 & 2.6 & 153 & 2.8 \\
\hline 2000-2004 & 1,642 & 29.5 & 3,919 & 70.5 & 1,380 & 24.8 & 125 & 2.2 & 137 & 2.5 \\
\hline 2001-2005 & 1,650 & 29.7 & 3,911 & 70.1 & 1,366 & 24.6 & 143 & 2.6 & 151 & 2.7 \\
\hline
\end{tabular}

Source: Health Surveillance Secretariat, Ministry of Health

* Five-year period;

** Municipalities with a mean of $\leq 2.4$ cases of visceral leishmaniasis in the five-year period;

*** Municipalities with a mean of $>2.4$ and $<4.4$ cases of visceral leishmaniasis in the five-year period;

\# Municipalities with a mean of $\geq 4.4$ cases of visceral leishmaniasis in the five-year period.

According to available data in the SINAN, from 2001 to 2005 the disease was distributed in the various age brackets, but occurred most frequently in children up to 10 years $(56.7 \%)$, with $43.4 \%$ of cases in children under five years. Males are proportionally more affected (60.4\%). In Brazil, visceral leishmaniasis shows a varied epidemiological profile due to climatic, physiogeographic, biological, and social characteristics that vary according to region and that interact to produce the disease. An example is the statistically significant differences in the age pro- file of human visceral leishmaniasis in the city of Teresina as compared to Campo Grande and Belo Horizonte (Table 3).

Based on observations, the change in the transmission pattern of visceral leishmaniasis from the countryside to cities, associated with the interiorization of AIDS in Brazil, has led to L. chagasi/HIV coinfection. According to SINAN data, the number of cases of coinfection increased from 21 in 2001 to 86 in 2005. This trend indicates that the juxtaposition of visceral leishmaniasis risk areas and HIV/AIDS may lead to 


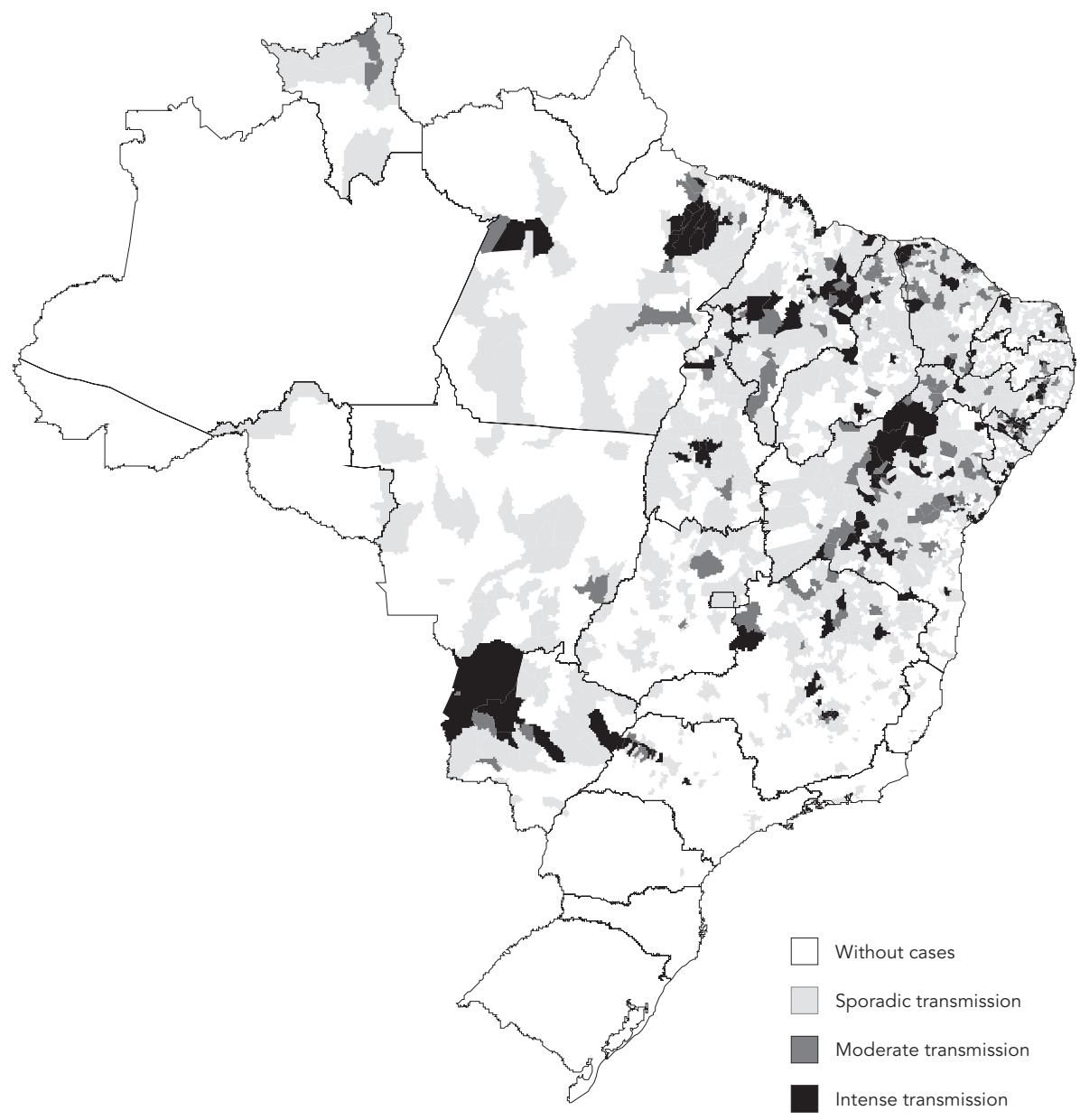

Source: Health Surveillance Secretariat, Ministry of Health.

an increase in cases of visceral leishmaniasis in young adults, thereby altering the profile of the disease in Brazil.

A recent evaluation of the SINAN, visceral leishmaniasis, and AIDS databases showed 176 cases of visceral leishmaniasis/AIDS coinfection. Mean age was 37 years and median age was $38( \pm 1.1)$, predominantly affecting males $(78 \%)$, with black individuals accounting for $53.4 \%$ of cases. Among the exposure categories for HIV/ AIDS, heterosexuals accounted for $56.3 \%$ of the cases, with a statistically significant difference between the genders $(p<0.001)$. The States with the highest shares of the total number of patients with visceral leishmaniasis/AIDS coin- fection were: Maranhão (16.5\%), Minas Gerais (14.8\%), São Paulo (13.6\%), and Mato Grosso do Sul $(9.1 \%) 26$.

The objectives of visceral leishmaniasis surveillance are to reduce the disease's morbidity and mortality rates through early diagnosis and treatment of human cases and to decrease the risk of transmission by controlling the populations of domestic reservoirs and vectors 12 .

The control strategies used in Brazil should be integrated and focused on diagnosis and adequate treatment of human cases, monitoring and euthanasia of seroreactive dogs, environmental management, and chemical control 12. A consultation of experts on visceral leishmaniasis held 
Cases of visceral leishmaniasis according to age bracket in the municipalities of Teresina (Piauí), Campo Grande (Mato Grosso do Sul), and Belo Horizonte (Minas Gerais), Brazil, 2001-2005

\begin{tabular}{|c|c|c|c|c|c|c|}
\hline \multirow{2}{*}{$\begin{array}{l}\text { Age bracket } \\
\text { (years) }\end{array}$} & \multicolumn{2}{|c|}{ Teresina } & \multicolumn{2}{|c|}{ Campo Grande } & \multicolumn{2}{|c|}{ Belo Horizonte } \\
\hline & $\mathrm{n}$ & $\%$ & $\mathrm{n}$ & $\%$ & $\mathrm{n}$ & $\%$ \\
\hline$<5$ & 294 & 63.2 & 102 & 28.4 & 97 & 25.6 \\
\hline 5-19 & 52 & 11.2 & 85 & 23.7 & 86 & 22.7 \\
\hline $20-49$ & 102 & 21.9 & 122 & 34.0 & 163 & 43.0 \\
\hline$\geq 50$ & 17 & 3.7 & 50 & 13.9 & 33 & 8.7 \\
\hline Total & 465 & 100.0 & 359 & 100.0 & 379 & 100.0 \\
\hline
\end{tabular}

N.B.: p-value for comparison of Teresina and Campo Grande < 0.001; p-value for comparison of Teresina and

Belo Horizonte $<0.001$.

Source: Database on Reportable Diseases (SINAN).

by the Pan-American Health Organization in November 2005 presented, discussed, and approved these guidelines for the Americas 27 .

Among the measures recommended for visceral leishmaniasis control, euthanasia of infected dogs is still a controversial point, but studies indicate that the disease in dogs precedes the appearance of human cases and that the odds of infection for humans increase in areas with high prevalence rates of canine infection where the vector is present 28 . It was also shown that elimination of infected dogs is the single most cost-effective measure for reducing human incidence 29 .

As for vector control measures, insecticides are widely used, but they vary as to efficacy 30,31 , duration of impact, and the resources required for different endemic areas 32 . The combination of chemical treatment of buildings and environmental management has proven effective in reducing vectors in the intradomiciliary setting 33 . Data from a recent study on control strategies in an urban area showed that chemical control and elimination of infected dogs, singly or jointly, reduced the incidence of human infection in 18 months by $24 \%$ to $39 \% 34$.

Despite well-defined guidelines for the control of visceral leishmaniasis and the investments made in organizing services and developing the proposed activities, vectors and reservoirs in urban areas pose the greatest challenges for the program to control the disease, given the need for better understanding of the vector's behavior in the urban setting, operational difficulties for per- forming the activities in sufficient time to impact the results, and the high cost of implementing the proposed measures. In relation to the vector, it is necessary to identify the factors that actually impact the control of Lu. longipalpis, given its high capacity to recolonize the urban environment and the complexity of identifying the sites with immature forms of the sand flies. Use of information like the vector's presence or absence, abundance, and infestation in the intra- and peridomicile is still limited for estimating the risk of transmission of visceral leishmaniasis, since there are no established parameters for such indicators.

The international scientific literature has presented some alternatives for visceral leishmaniasis vector and reservoir control, such as: dipping dogs with insecticides, vaccines, and pyrethroid-impregnated collars, among others. Some of these alternatives have shown satisfactory results, while for others the results are still inconclusive, and investment in further research is needed.

In recent years, the Brazilian Ministry of Health has invested in the search for new knowledge and alternatives for the control of this endemic. The main lines of research focus on the implementation of human and canine laboratory diagnosis, treatment of visceral leishmaniasis patients, evaluation of the effectiveness of vector and reservoir control strategies, and new technologies that can contribute to the implementation of surveillance and control measures for visceral leishmaniasis in the country. 


\section{Resumo}

A urbanização da leishmaniose visceral tem sido relacionada a modificações ambientais causadas por ações antrópicas, pelo rápido processo migratório, pela interação e mobilização de reservatórios silvestres e cães infectados para áreas sem transmissão, e pela adaptação do vetor Lutzomiya longipalpis ao peridomicílio. Entre 1980 e 2005, o Brasil registrou 59.129 casos de leishmaniose visceral, sendo 82,5\% na Região Nordeste. Gradativamente, a leishmaniose visceral expandiu-se para as regiões Centro-Oeste, Norte e Sudeste, passando de 15\% dos casos em 1998 para 44\% em 2005. Entre 1998 e 2005 foram registrados casos autóctones em 1.904 (34,2\%) diferentes municípios brasileiros. O controle vetorial e de reservatórios representam os maiores desafios para o controle da doença, dado a necessidade de melhor conhecer o comportamento do vetor no ambiente urbano, as dificuldades operacionais e o alto custo de execução. Nos últimos anos, o Ministério da Saúde tem investido em pesquisas sobre diagnóstico laboratorial humano e canino, tratamento dos pacientes, avaliação da efetividade das estratégias de controle, bem como de novas tecnologias que possam contribuir na implementação das ações de vigilância e controle da leishmaniose visceral no Brasil.

Reservatórios de Doenças; Controle de Vetores; Leishmaniose Visceral; Urbanização; Vigilância Epidemiológica

\section{Contributors}

A. N. S. Maia-Elkhoury was responsible for the literature review, analysis of part of the data, and the article's overall description. J. M. Sena was responsible for the entomological information. M. L. Sousa-Gomes prepared the databanks. W. A. Alves was responsible for the information on reservoirs. E. A. Luna conducted the overall revision of the article and made contributions to all the sections. All the authors reviewed the final version.

\section{References}

1. Cunha AM, Chagas E. Estudos sobre o parasito. Mem Inst Oswaldo Cruz 1937; 32:329-37.

2. Lainson R, Shaw JJ. Evolution, classification and geographical distribution. In: Peters W, KillickKendrick R, editors. The Leishmaniases in Biology and Medicine. London: Academic Press; 1987. p. 1-20.

3. Rebêlo JMM, Mendes WA, Costa JML, Cavaleiro N. Lista preliminar das espécies do gênero Lutzomyia, França, 1924 (Psychodidae, Phlebotominae) do Estado do Maranhão, Brasil. Cad Saúde Pública 1996; 12:545-9.

4. Santos SO, Arias J, Ribeiro A, Hoffmann MP, Freitas RA, Malacco MAF. Incrimination of Lutzomyia cruzi as a vector of American Visceral Leishmaniasis. Med Vet Entomol 1998; 12:315-7.
5. Desjeux P. Leishmaniasis: current situation and new perspectives. Comp Immunol Microbiol Infect Dis 2004; 27:305-18.

6. Missawa NA, Veloso MAE, Maciel GBML, Souza CO, Rangel EF, Michalsky EM, et al. Evidência de transmissão de leishmaniose visceral por Lutzomyia cruzi no município de Jaciara, Estado de Mato Grosso. In: XXII Reunião Anual de Pesquisa Aplicada em Doença de Chagas e Leishmanioses. Uberaba: Centro Educacional e Administrativo, Universidade Federal do Triângulo Mineiro; 2006. p. 74 .

7. Deane LM, Deane MP. Encontro de Leishmanias nas vísceras e na pele de uma raposa, em zona endêmica de calazar, nos arredores de Sobral, Ceará. O Hospital 1954; 45:419-21. 
8. Deane LM. Leishmaniose visceral no Brasil. Estudos sobre reservatórios e transmissores realizados no Estado do Ceará [Thesis]. Rio de Janeiro: Serviço Nacional de Educação Sanitária; 1956.

9. Sherlock IA, Miranda JC, Sadirgusky M, Grimaldi Jr. G. Natural infection of the opossum Didelphis albiventris with Leishmania donovani in Brazil. Mem Inst Oswaldo Cruz 1984; 79:511.

10. Marzochi MCA, Sabrosa PC, Toledo LM, Marzochi KBF, Tramontano NC, Rangel-Filho FB. Leishmaniose visceral na cidade do Rio de Janeiro, Brasil. Cad Saúde Pública 1985; 1:5-17.

11. Sherlock IA. Ecological interactions of visceral leishmaniasis in the state of Bahia. Mem Inst Oswaldo Cruz 1996; 91:671-83.

12. Departamento de Vigilância Epidemiológica, Secretaria de Vigilância em Saúde, Ministério da Saúde. Manual de vigilância e controle da leishmaniose visceral. Brasília: Ministério da Saúde; 2004.

13. Migone LE. Un caso de kala-zar a Asunción (Paraguay). Bull Soc Path Exot 1913; 6:118-20.

14. Penna HA. Leishmaniose visceral no Brasil. Bras Med 1934; 18:940-50.

15. Alencar JE. Expansão do Calazar no Brasil. Ceará Méd 1983; 5:86-102.

16. Chagas E, Chagas AW. Notas sobre a epidemiologia da leishmaniose visceral americana no Mato Grosso. O Hospital 1938; 13:471-80.

17. Alencar JE, Dietze R. Leishmaniose visceral (calazar). In: Veronesi R, organizador. Doenças infecciosas e parasitárias. Rio de Janeiro: Editora Guanabara Koogan; 1991. p. 706-17.

18. Deane LM, Deane MP. Observações sobre a transmissão da leishmaniose visceral no Ceará. O Hospital 1955; 48:347-64.

19. Silva AR, Viana GM, Varonil C, Pires B, Nascimento MD, Costa JM. Leishmaniose visceral (calazar) na ilha de São Luís, Maranhão, Brasil: evolução e perspectivas. Rev Soc Bras Med Trop 1997; 30:359-68.

20. Tauil PL. Perspectivas de controle de doenças transmitidas por vetores no Brasil. Rev Soc Bras Med Trop 2006; 39:275-7.

21. Lainson R. Demographic changes and their influence on the epidemiology of American leishmaniasis. In: Service MW, editor. Demography and vector-borne diseases. Boca Raton: CRC Press; 1989. p. 85-106.

22. Dias FOP, Lorosa ES, Rebelo JMM. Fonte alimentar sangüínea e a peridomiciliação de Lutzomyia longipalpis (Lutz \& Neiva, 1912) (Psychodidae, Phlebotominae). Cad Saúde Pública 2003; 19:1373-80.
23. Costa CH, Pereira HF, Araújo MV. Epidemia de leishmaniose visceral no Estado do Piauí, Brasil, 1980-1986. Rev Saúde Pública 1990; 24:361-72.

24. Bevilacqua PD, Paixão HH, Modena CM, Castro MCPS. Urbanização da leishmaniose visceral em Belo Horizonte. Arq Bras Med Vet Zootec 2001; 53:1-8.

25. Maia-Elkhoury ANS. Avaliação dos registros de morbimortalidade da leishmaniose visceral nos sistemas de informações do SUS [Masters Thesis]. Salvador: Instituto de Saúde Coletiva, Universidade Federal da Bahia; 2005.

26. Maia-Elkhoury ANS, Lucena F, Sousa-Gomes ML, Alves WA, Paz L. Co-infecção da leishmaniose visceral e AIDS no Brasil. Rev Soc Bras Med Trop 2007; 40 Suppl 1:124.

27. Organização Pan-Americana da Saúde. Consulta de expertos OPS/OMS sobre leishmaniasis visceral en las Américas. http://www.panaftosa.org.br/ inst/zoonosis/LEISHMANIOSIS/Inf_final_leish_ 2005.pdf (accessed on 03/Mar/2007).

28. Di Lorenzo C, Proietti FA. Leishmaniose visceral canina como fator de risco para a leishmaniose visceral humana: o que sabemos e o que não sabemos ainda. Rev Soc Bras Med Trop 2002; 35 Suppl 3:75-81.

29. Camargo-Neves VLF, Katz G, Rodas LAC, Poleto DW, Lage LC, Spinola RMF, et al. Utilização de ferramentas de análise espacial na vigilância epidemiológica de leishmaniose visceral americana - Araçatuba, São Paulo, Brasil, 1998-1999. Cad Saúde Pública 2001; 17:1263-7.

30. Marzochi MCA, Marzochi KBF. Tegumentary and visceral leishmaniases in Brazil - emerging anthropozoonosis and possibilities for their control. Cad Saúde Pública 1994; 10 Suppl 2:359-75.

31. Vieira JBF. O controle das leishmanioses no Brasil. Hiléia Méd 1987; 8:13-35.

32. Gomes AC, Camargo-Neves VLF. Estratégia e perspectivas de controle da leishmaniose tegumentar no Estado de São Paulo. Rev Soc Bras Med Trop 1998; 31:553-8.

33. Camargo-Neves VLF. Aspectos epidemiológicos e avaliação das medidas de controle da leishmaniose visceral americana no Estado de São Paulo, Brasil [Doctoral Dissertation]. São Paulo: Faculdade de Saúde Pública, Universidade de São Paulo; 2004.

34. Werneck GL. Leishmaniose visceral em meio urbano: avaliação das estratégias de controle utilizando uma abordagem espacial. Brasília: Secretaria de Vigilância em Saúde, Ministério da Saúde; 2007.

Submitted on 06/Mar/2008

Approved on 25/Mar/2008 